\title{
Priority Level in the Developing of Islamic Education in the Association of Muslim Ethics in Thonburi, Bangkok
}

\author{
Dr. Prasert Suksaskawin \\ Centre of Islamic Studies, Siam Technology Collage Thonburi, Bangkok
}

\begin{abstract}
Education provides learning process to human through advancement is possible in regard to growth of society. The management of education is essence for any organization and authority for long term advantage especially manage to basic education system. This research deals with the priority level of Muslim Shia sect of Islam regarding to Islamic education under the association of Muslim ethics in Thonburi, Bangkok. The results shows priority of Muslim Shia sect of Islam under the association of Muslim ethics towards the Islamic education is moderate even the expectations are high. To find results there are conducted survey on personality of parents, community leaders, students, teachers, and executive directors of association have been done and data of secondary sources have been used to analyzed to obtain the objectives of the study.
\end{abstract}

Keywords: Islamic education, Management, Priority, personality, etc.

\section{Introduction}

Society is a system of number of institutions which are connected to the whole system of society. Each institution of system has a different responsibility and their duties to serve the needs of society. There are social institutions, political institutions, educational institutions, religious institutions and Institutes of economic affairs which are parts of a system play an important role in a society and its function. At the same time members of society play as acts to happen in process manner. The consistent in social environment needs proper functioning of society with organizing and guiding manner. Education is important for members of a society because education helps individuals to have to ideas, intellectuality, morality and ethical values for good life and applied these good things in the right way and also understand and knowing changing situations in different parts of society.

Education is also an impetus element for progressive society and through which nations developed and take a path of progress and prosperity. In this way people of the nations have decent well being. There will be dark and blind life if there is no education and also it happens when management of basic education is in not proper way. Education is a process of developing of whole people in regard to mind and habits and useful for future generations. This education tool is important for unity among citizens of a nation. Education contributes towards stability in social, cultural, economic and political landscapes in a country. Education is a process of producing intellectuality and making morality in society which helping to solve of many problems of society. Learning process is essence of education which helpful to a person to grow in life and also progressive growth of society. Knowledge transformation through teaching and seminars which enhance cultural heritage and academic progression. To create learning environment which contributes in individual learning spirit for throughout life. 


\section{Objectives of the Study}

a) To study the expectations of the Muslim Shia sect of Islam under the Association of Muslim ethics to manage basic education in Thonburi, Bangkok.

b) To compare the expectations from personality traits of parents, teachers and community leaders of the Muslim Shia sect of Islam under the Association of Muslim ethics to manage basic education in Thonburi, Bangkok.

Independent Variables

\begin{tabular}{|l|l|}
\hline $\begin{array}{l}\text { The status of individuals in } \\
\text { the community }\end{array}$ & $\begin{array}{l}\text { Priorities in the second } \\
\text {-Executives Association of } \\
\text { Muslim moral teachers. } \\
\text {-parents } \\
\text {-Community Leaders } \\
\text { - teachers }\end{array}$ \\
of Islamic education. \\
2-The administration of the \\
Association of Muslim \\
ethics.
\end{tabular}

This research focuses on the priorities for Muslim Shia sect of Islam to manage the basic education and compare the personality of community leaders, parents, students, teachers and administrators from the association of promoting Muslim ethics in Thonburi, Bangkok. The sample data of 80 people on personality of community leaders, parents, students, teachers and administrators from the association of promoting Muslim ethics in Thonburi, Bangkok have been taken and analyzed by using of methods of by frequency, percentage, average, standard deviation, and software packages SPSS XI for Windows has been used.

\section{Summary and Results of the Study}

The summary of the study finds the expectations of Muslim Shia sect of Islam in order to manage the Islamic education of the Association of Muslim ethics in Thonburi, Bangkok is quite high but comparatively priority wise it is low in nature. The curriculum of Islamic education and assessment of the course have been taken to study with the role and responsibility of personality of parents, community leaders, teachers and executive committee of the association of Muslim ethics. The results shows from the side of Muslim Shia sect of Islam they get less budget but expectation so high from them and at the same time priority level they are in moderate after conducts personality test of parents, community leaders, teachers and executive committee of the association of Muslim ethics.

\section{References and Bibliography}

[1] Kanjanacnaraks (1992), Curriculum Deverlopment, 2nd edition Genesis: Printing Silpakorn University.

[2] KriengsakChareonwongsak (2000), South wise Educators, Edition 4: A blockade net Dhaka printing.

[3] Religious Affairs (1992), Registration mosque in Thailand, The degree Snoopy Waithayopathum,Bangkok

[4] Sheikh Sharif Hadi (2009), Foundation Imam al-Hadi (as), Grade 5 textbook Islam Bangkok.

[5] Sheikh Sharif Hadi (2009), Foundation Imam al-Hadi (as), textbook Islam grade 6 Bangkok.

[6] Seiji Tanaka (1995), Development of the historical Muslim Community School. Bangkok: (Mimeograph document), Institute of Asia-Pacific Studies, Srinakharinwirot University. 
In the study, the expectations of the Muslim Shia sect of Islam in the management of basic education.Association of Muslim ethics Thonburi, Bangkok. There are important issues to be discussed The assessment follows the philosophy of the course The study found that Parents Shia Muslim community leaders. Teachers and Executive Committee of the Association of Muslim ethics.Is of the opinion that the overall Expectations are high. Budgetary assessment budgetary The study found that Parents Shia Muslim community leaders, teachers and the board of directors of the Association of Muslim ethics. Is of the opinion that the overall Expectations are low level. This may be due The budget received from the Association of Muslim ethics agencies are not much and too little. But it can be managed to a certain extent in various aspects of school supplies, teaching, assessment and instruction. The study found that Parents Shia Muslim community leaders, teachers and the board of directors of the Association of Muslim ethics. Is of the opinion that the overall The expectations are moderate. This may be due BYOD instruction to not convenient enough. Throughout the course of the devices may not stylish enough to make a proper assessment of the level of measurement and evaluation, assessment, measurement and evaluation. The study found that Parents Shia Muslim community leaders, teachers and the board of directors of the Association of Muslim ethics. Is of the opinion that the overall The expectations are moderate. 